\title{
Implementation of Cooperative Learning Treffinger Type to Improve the Understanding of Class VI Students
}

\author{
Yullia Susilaningtyas ${ }^{1}$, M. Bahri Musthofa ${ }^{2}$ \\ ${ }^{12}$ State Islamic Sunan Ampel of Surabaya, Indonesia \\ * e-mail: susilaningtyasyullia@gmail.com
}

\begin{abstract}
This study aims to determine the application of the Treffinger learning model to improve the understanding of grade VI students. This research is a Classroom Action Research (CAR) with Kurt Lewin's model. The results showed that the results of teacher observations in the first cycle were $72.2 \%$, increasing to $91.6 \%$ in the second cycle. This increase also occurred in the observation of student activity in the first cycle, namely $68.75 \%$, increasing to $90.62 \%$ in the second cycle. Increasing the learning process has an impact on increasing students' understanding of the natural and social appearance material of neighboring countries. This can be seen from the increase in the average score of students in the first cycle from 74.76 to 82.80 in the second cycle which was classically complete. Likewise, student learning completeness in the first cycle was $65.38 \%$ to $92.30 \%$ in the second cycle with a good category.
\end{abstract}

Keywords: Treffinger learning model; social

How to cite : Susilaningtyas, Y., \& Musthofa, M. B. (2021). Implementation Of Cooperative Learning Treffinger Type To Improve The Understanding Of Class VI Students. Pedagogi: Jurnal Ilmu Pendidikan, 21(2), 107-113. https://doi.org/https://doi.org/10.24036/pedagogi.v21i2.1073

Licensees may copy, distribute, display and perform the work an make derivative and remixes based on it only if
they give the author or licensor the credits (attributtion) in the manner specified by these. Licensees may copy,
distribute, display, and perform the work and make derivative works and remixes based on it only for non-
commercial purposes

\section{INTRODUCTION}

Social Science (IPS) is a subject that has a concept of thinking based on the reality of the social conditions that exist in the student environment. Through Social Sciences learning (IPS) it is hoped that they can become good citizens and be able to critically examine the social life around them and be able to participate actively in the environment, life both in society and in the world.

Problems faced in the subject of Social Sciences (IPS), especially in the material of the natural and social appearance of neighboring countries. The score for the Social Science (IPS) subject with 26 participants based on the results of daily tests, material on the natural and social features of neighboring countries on the basic competence comparing the natural and social features of neighboring countries is only 53, 84\%. That means only 14 students managed to achieve the specified minimum completeness criteria (KKM), namely 75.

Based on the results of the researchers' reflection with one of the teachers of the Social Sciences (IPS) subject at MI NU Kedensari Tanggulangin Sidoarjo on September 12, 2016, the factors behind this include students who do not master the material of the natural and social appearances of neighboring countries, namely students. find it difficult to express opinions about the problems being faced by neighboring countries.

The second factor, namely the material of the natural and social appearance of neighboring countries is very complex, meaning that the time provided by the school is not enough to discuss 
all the material in detail so that the teacher only provides material in general without providing additional material that is in accordance with the current conditions this so as to open the horizons of students.

The first formulation of the problem, how is the implementation of Treffinger type cooperative learning in order to improve understanding of Social Sciences (IPS) subjects on the natural and social appearance of neighboring countries in class VI MI NU Kedensari Tanggulangin Sidoarjo.

The second formulation of the problem, How to increase understanding of Social Sciences (IPS) subjects on the material of the natural and social appearance of neighboring countries through cooperative learning type Treffinger for grade VI students at MI NU Kedensari Tanggulangin Sidoarjo.

Understanding has various meanings when viewed from various perspectives. Understanding in the context of education that occurs between students and teachers as well as between one student and another, so we need an understanding of both self-understanding and understanding of others (understanding the others). A deep understanding of themselves in this case is that a teacher will not easily understand the characteristics of students if they cannot understand themselves well (Syaodih, 2005). The following is a table of understanding indicators (Wowo, 2012).

Tabel 1. Understanding Indicators

\begin{tabular}{cll}
\hline No. & Understanding Indicators & \multicolumn{1}{c}{ Example } \\
\hline 1 & Interpret & Decipher in your own words \\
2 & Provide examples & Provide examples of various artistic painting styles \\
3 & Classify & Observe or describe cases of mental confusion \\
4 & Conclude & Write a short summary of the video \\
5 & Guessed & Draw conclusion \\
6 & Comparing & Comparing historical events with past events \\
7 & Explain & Explain the causes of war \\
\hline
\end{tabular}

Cooperative Learning consists of 2 words, namely cooperative which means working together. The second word is learning which means learning. The conclusion that can be drawn from these two words is that cooperative learning is a form of learning activity in which there is a process for working together in order to achieve learning goals (Ma'mur, 2016).

Basically, learning success according to cooperative learning is not determined by the individual as a whole, but learning acquisition will be better if done together in small, wellstructured learning groups. This Cooperative Learning learning model will develop understanding and attitudes in accordance with real life in society so that it will increase motivation, productivity and the acquisition of learning outcomes (Solihatin, 2017).

There are several class management to support the creation of a cooperative classroom atmosphere, including: 1) room arrangement, which includes the seating position of students in groups to save time, so group formation can be done one day before the learning process is carried out. Apart from that, the room arrangement also includes the storage of student equipment. A teacher can group student equipment into a box so that there is no lending and borrowing process during the lesson; 2) special recognition bulletin, where the teacher can use diagrams or posters containing positive notes; 3) a special recognition ceremony the accumulation of the number of points received by each group to get a gift from the teacher. (Rahman, 2011).

This Treffinger learning model has an effort to integrate the cognitive and affective aspects of students to find a solution in solving problems, meaning that students are given the opportunity to creatively solve their own problems, while the teacher's task is to guide students so that students do not get out of these problems (Huda, 2013).

Provide opportunities for students to understand concepts in order to solve a problem, make students active in the learning process, develop students 'thinking skills because they must be able to solve a problem independently, develop students' ability to define problems, collect data, 
analyze data, build hypotheses and experiments to solve problems and apply new knowledge that students have into new situations or more complex problems (Huda, 2013).

Students can think critically, students can develop skills to express opinions, students can train to think quickly in solving a problem, students can practice collecting knowledge information independently and students can see a problem from various perspectives (Huda, 2013).

\section{METHODS}

This research is a Classroom Action Research (PTK). Classroom Action Research is research conducted by a teacher in his own class by planning, implementing and reflecting on collaborative actions with the aim of improving performance as a teacher so that student learning outcomes will increase. Classroom action research is a qualitative research, although the data collected may be quantitative in nature but the description is still descriptive in the form of words (Madya, 2007).

This classroom action research uses the Kurt Lewwin model. The reason for using this model is because the stages in Kurt Lewwin's model are very organized. Kurt Lewwin's model consists of four stages in conducting research, namely: Planning, which is the process of determining a program or planning that comes from the researcher's idea, the second is action or action, namely the implementation of research carried out by the researcher with a plan prepared by the researcher., then observation (Observing), namely observations made to determine the effectiveness of the action or collect information about various deficiencies in the action taken and reflection (Reflecting), namely activities about analyzing the results of observations so as to generate new programs or plans (Madya, 2007).

Data collection techniques using observation, interviews and tests. Observation results obtained through observation activities, researchers get a reflection to make improvements in subsequent learning activities. The method of data collection was by using observation to collect data, namely the activities of the students in cycle I and cycle II and the activities of the teacher in cycle I and cycle II.

The second data collection is the process of interviewing researchers with social studies subject teachers to get results about the number of students, student characteristics, the curriculum used in social studies subjects, minimum completeness criteria, learning tools used by teachers, learning resources used, methods and the media used during the learning process.

Data collection using tests was used to collect data on the ability to identify the first cycle and the ability to identify the second cycle. The test used in this study is a written essay test and the documentation that the researchers got in this study was the students' daily test scores. In this study, the documentation method used to collect data is to support data.

The data analysis used is qualitative and quantitative analysis. This qualitative descriptive analysis is in the form of teacher activity observation sheets, student activity observation sheets, interviews with subject teachers and interviews with students.

This study uses quantitative analysis, namely analysis using quantitative analytical tools where the analysis uses mathematical models, statistical models and ecomotor. The researcher presents the results of the analysis in numerical form and is then explained and interpreted in a descriptive form or description

The analysis uses the class average value and the classical learning completeness presentation. To calculate the average value, namely by adding the value obtained by students with the number of students in the class so that the average value is obtained.

Furthermore, the average score obtained is classified into a predicate which has the following scale: To find out the percentage of student learning completeness in cycle I and cycle II, the percentage formula is used. A student is said to have completed learning if he gets a value of 75 because it is in accordance with the Minimum Completeness Criteria that has been 
determined by the school and is classically complete if the class reaches a minimum of $85 \%$ which has achieved success in the learning process.

\section{FINDING AND DISCUSSIONS}

Researchers and teachers reflect to find the factors that cause unsuccessfulness in the teaching and learning process of the material of the natural and social appearances of neighboring countries, namely 1) students do not master the natural and social appearance of neighboring countries and find it difficult to express opinions about the problems at hand. by neighboring countries, 2) Students find it difficult to distinguish between one ethnic group and another, considering that there are various ethnic groups from each country and 3 ) the third factor, namely the material of the natural and social appearance of neighboring countries is very complex, meaning with the time provided by the school is not enough to discuss all the material in detail so that the teacher only provides material in general without providing additional material that is in accordance with the current conditions of society so as to be able to open students' horizons.

Based on the results of observations at the beginning of the study it can be proven by the following table

Table 2. Distribution of Student Daily Test Values

\begin{tabular}{clc}
\hline No. & \multicolumn{1}{c}{ Evaluation aspect } & Score \\
\hline 1 & Average score of the formative test & 72,23 \\
2 & The number of students who have completed their studie & 14 \\
3 & The percentage of student learning completeness & $53,84 \%$ \\
\hline
\end{tabular}

Table 3. Learning Outcomes of Cycle I Student Tests

\begin{tabular}{cccc}
\hline No. & Name & Score & Information \\
\hline 1 & ASR & 80 & Complete \\
2 & AL & 80 & Complete \\
3 & AAS & 90 & Complete \\
4 & AMS & 85 & Complete \\
5 & ANS & 88 & Complete \\
6 & AMS & 60 & Uncomplete \\
7 & AW & 88 & Complete \\
8 & SC & 58 & Complete \\
9 & CRY & 87 & Complete \\
10 & EDPR & 86 & Uncomplete \\
11 & FMU & 56 & Complete \\
12 & MIF & 88 & Uncomplete \\
13 & MSM & 60 & Uncomplete \\
14 & MRP & 55 & Complete \\
15 & MA & 85 & Uncomplete \\
16 & MAR & 57 & Uncomplete \\
17 & MAS & 60 & Uncomplete \\
18 & MHS & 60 & Complete \\
19 & NFA & 86 & Uncomplete \\
20 & NNS & 56 & Complete \\
21 & NNL & 89 & Uncomplete \\
22 & RNA & 50 & Complete \\
24 & SL & 81 & Uncomplete \\
25 & R.R FYN & 50 & Complete \\
26 & ZA & 81 &
\end{tabular}


Table 4. Distribution of Student Scores in Cycle I

\begin{tabular}{clc}
\hline No. & \multicolumn{1}{c}{ Evaluation aspect } & Score \\
\hline 1 & Average score of the formative test & 74,76 \\
2 & The number of students who have completed their studie & 17 \\
3 & The percentage of student learning completeness & $65,38 \%$ \\
\hline
\end{tabular}

Table 5. Student Learning Outcomes in Cycle II

\begin{tabular}{cccc}
\hline No. & Name & Score & Information \\
1 & ASR & 85 & Complete \\
2 & AL & 89 & Complete \\
3 & AAS & 92 & Complete \\
4 & AMS & 95 & Complete \\
5 & ANS & 88 & Complete \\
6 & AMS & 96 & Complete \\
7 & AW & 90 & Complete \\
8 & SC & 95 & Complete \\
9 & CRY & 93 & Complete \\
10 & EDPR & 89 & Complete \\
11 & FMU & 90 & Complete \\
12 & MIF & 88 & Complete \\
13 & MSM & 90 & Complete \\
14 & MRP & 95 & Complete \\
15 & MA & 85 & Complete \\
16 & MAR & 90 & Complete \\
17 & MAS & 93 & Complete \\
18 & MHS & 89 & Complete \\
19 & NFA & 92 & Complete \\
20 & NNS & 70 & Uncomplete \\
21 & NNL & 89 & Complete \\
22 & RNA & 73 & Uncomplete \\
24 & SL & 95 & Complete \\
25 & R.R FYN & Complete \\
26 & ZA & 95 & Complete \\
\hline
\end{tabular}

Table 6. Distribution of student scores in cycle II

\begin{tabular}{clc}
\hline No. & \multicolumn{1}{c}{ Evaluation aspect } & Score \\
\hline 1 & Average score of the formative test & 86,03 \\
2 & The number of students who have completed their study & 24 \\
3 & The percentage of student learning completeness & $92,30 \%$ \\
\hline
\end{tabular}

The learning activity begins with the teacher saying greetings but it does not get a good response from students because only a small part of it answers greetings. Followed by a prayer led by the Teacher. The next step is for the teacher to give Ice Breaking with the title "COCONUT" with the aim of giving enthusiasm and concentration to students. Students are very enthusiastic when doing Ice Breaking. Each student pays close attention to the instructions from the teacher

The teacher gives apperception to construct students' thoughts on the subject matter to be taught. The responses given by students were only partially when answering questions from the teacher and continued by the teacher writing the titles on the board and conveying the learning objectives that would be achieved in the learning process clearly and easily understood.

Before delivering the material, the teacher tries to dig up students' knowledge by asking questions. To find out the students' abilities, the teacher explains the material on the power point slides and the students write down some of the points on the slides to understand each sub-chapter of the material. After delivering the material, the teacher conducts questions and answers with 
students. The teacher divides into 5 groups with details of each group consisting of 4-5 people. The teacher distributes Group Student Worksheets in the form of 2 columns, namely the comparison between 2 countries in terms of natural and social appearance. The teacher gives a duration of 15 minutes. As long as students carry out the discussion process, the teacher assesses the student activities carried out. When the specified duration has expired, students collect Student Worksheets (LKS). Groups that can collect assignments quickly will get points from the teacher. After that, each group representative presented the results of their discussion

The teacher reflects on the results of the discussion and the learning process that has been carried out by the students and then the teacher gives description questions to find out the students' understanding of the material. After that, the teacher provides reinforcement of the subject matter. At the end of the lesson, the teacher closes the lesson by saying hamdalah with the students and encourages students to study natural and social appearance materials.

The learning activity begins with the teacher saying greetings then continues with prayer. After praying, the teacher checks the attendance of the students. The teacher gives Ice Breaking with the title "APPLE TREE" with the aim of giving enthusiasm and concentration to students. The teacher gives apperception to construct students' thoughts on the subject matter to be taught. The teacher writes the title on the board and conveys the learning objectives that will be achieved in the learning process.

To find out the students' abilities, the teacher explains the material in the Scrap Book Oint and the students write down some of the points in the scrap book to understand each sub-chapter of the material. After delivering the material, the teacher conducts questions and answers with students. The teacher divides into 5 groups with details of each group consisting of 4-5 people. The teacher distributes Group Student Worksheets (LKS) in the form of 2 columns, namely the comparison between 2 countries in terms of natural and social appearance. The teacher gives a duration of 15 minutes. As long as students carry out the discussion process, the teacher assesses the student activities carried out. When the specified duration has expired, students collect Student Worksheets (LKS). Groups that can collect assignments quickly will get points from the teacher. After that, each group representative presented the results of their discussion.

The teacher reflects on the results of the discussion and the learning process that has been carried out by the students and then the teacher gives description questions to find out the students' understanding of the material. After that, the teacher provides reinforcement of the subject matter. At the end of the lesson, the teacher closes the lesson by saying hamdalah with the students and encourages students to study natural and social appearance materials.

\section{CONCLUSION}

Implementation of Treffinger-type Cooperative Learning, material on the natural and social features of neighboring countries can be carried out well, if it is carried out in two cycles. He carried out two cycles, because the first cycle was not successful. This is because teachers are not able to condition students. After doing reflection in cycle I, cycle II can be successful. This can be proven by the increase in the results of observations of teacher activities and the results of observations of student activities. The result of the teacher's observation in the first cycle was $72.2 \%$ and the result of the observation in the second cycle was $91.6 \%$. While the results of observations of student activity in the first cycle were $68.75 \%$ and the results of the observations in the second cycle were $92.62 \%$.

After the implementation of the Treffinger Cooperative Learning Type, it shows an increase in understanding of the material on the natural and social appearance of neighboring countries. This can be seen from the increase in student learning completeness in each cycle. In the first cycle the average value obtained was 74.76 with a completeness percentage of $65.38 \%$, because in the first cycle it had not reached the completeness indicator, then the second cycle was carried out. In cycle II, the students' average score was 82.80 with the percentage of completeness was 
$92.30 \%$. From these data it can be seen that in each cycle it has increased to meet the completeness indicator in cycle II.

\section{REFERENCES}

Huda, M. (2013). Model-Model Pengajaran dan Pembelajaran. Pustaka Pelajar.

Ma'mur, J. (2016). Cooperative Learning Pembelajaran Aktif, Kreatif dan Tidak Membosankan. Diva Press.

Madya, S. (2007). Penelitian Tindakan Kelas. Alfabeta.

Rahman, A. (2011). Manajemen Kelas untuk Guru Sekolah Dasar. Kencana Prenada Media.

Solihatin, E. (2017). Cooperative Learning, Analisis Model Pembelajaran IPS. Bumi Aksara.

Syaodih, N. (2005). Landasan Psikologi Proses Pendidikan,. Remaja Rosdakarya.

Wowo, S. (2012). Taksonomi Kognitif, Bandung. Remaja Rosdakarya. 